\title{
THE EFFECT OF ASBESTOS AND STONE-WOOL FIBRES ON SOME CHEMOKINES AND REDOX SYSTEM OF PULMONARY ALVEOLAR MACROPHAGES AND PNEUMOCYTES TYPE II
}

\author{
Erzsébet Tátraia , Marta Brózik ${ }^{b}$, Zuzana Kováčikovác, Magdolna Horváth ${ }^{\mathrm{a}}$
}

\author{
a Fodor József National Center for Public Health, Budapest, Hungary \\ ${ }^{b}$ National Institute of Rheumatology and Physiotherapy, Budapest, Hungary \\ c Research Base of Slovak Medical University, Bratislava, Slovakia \\ e-mail:tatrai@fjokk.hu
}

Received: June 10, 2005; Accepted: September 25, 2005

Key words: Stone-wool/Alveolar macrophages/Pneumocytes type II/Antioxidant system/Chemokines

The in vitro effect of stone-wool has been studied in primary cultures of pulmonary alveolar macrophages (AM) and type II pneumocytes (T2) by morphological, biochemical and immunological methods. UICC crocidolite was applied as a positive control. Although stone-wool brought about frustrated phagocytosis, it did not induce serious membrane damage, whereas crocidolite gave rise to very severe membrane alterations. Stone-wool significantly reduced the activity of $\mathrm{Cu}, \mathrm{Zn}$ /superoxide dismutase (SOD) in alveolar macrophages and significantly decreased the activity of $\gamma$-glutamyl transpeptidase (GGT) in pneumocytes type II. Crocidolite, on the other hand, decreased the activity of all enzymes (glutathione peroxidase - GSH-Px, glutathione reductase - GSH-Rd) of glutathione metabolism in alveolar macrophages. It decreased the activity of all enzymes in pneumocytes type II except for $\mathrm{Cu}, \mathrm{Zn} / \mathrm{SOD}$. After exposure to stone-wool, the production of inflammatory proteins, macrophage chemoattractant protein-1 (MCP-1) and macrophage inhibitory protein-1 $\alpha$ (MIP-1 $\alpha)$ increased in both cultured cells but did not reach the level induced by crocidolite.

Although this study provided a useful insight in the toxicity of the stone-wool, we can not draw the conclusions how the intact pulmonary tissue may respond on the exposure to these fibres, exclusively based on the in vitro tests.

\section{INTRODUCTION}

Stone-wool is widely used as a replacement for asbestos and in horticulture. Stone-wool consists of calciummagnesium-aluminium silicate, with ferric and ferrous oxide as a surface layer. Although the main exposure route is the respiratory tract only limited or unsubstantiated information concerning its long-term inhalation toxicity is available. Therefore the long-term effect of stone-wool on the lungs was studied. Further data on its direct toxic effects in pneumocytes and alveolar macrophages are scare and there is only inadequate evidence for carcinogenicity of stone-wool in humans ${ }^{1}$.

Since more and more results imply that the formation of free radicals plays a role in the development of fibrosis and malignancies ${ }^{2,3}$, the pulmonary antioxidant defense mechanism was studied in alveolar macrophages and type II pneumocytes. These cells are the most important components acting against xenobiotics in the detoxification processes of the lungs. Because close connection is presumed between the production of proinflammatory proteins and the release of free radicals, secretion of MCP-1 and MIP-1 $\alpha$ (which contribute to the initiation and outcome of inflammation in the lungs ${ }^{4}$ ) by alveolar macrophages and type II pneumocytes was studied. Therefore in vitro studies were carried out to clarify the long-term effect of stone-wool and the possible role of free radicals and chemokines.

\section{MATERIALS AND METHOD}

Three series of experiments were performed and six animals were used in each experiment. Alveolar macrophages and type II pneumocytes were isolated from male Sprague-Dawley rats (Charles River Hungary, Isaszeg) weighing 180-200 g. Under intraperitoneal sodium pentobarbitone anaesthesia ( $35 \mathrm{mg} . \mathrm{kg}^{-1}$ of Nembutal, Sanofi, Budapest), the animals were exsanguinated by cutting the abdominal aorta. Having open the chest, the lungs were perfused through the pulmonary artery with $0.9 \%$ saline, the lungs and trachea were removed from the thoracic cavity, and subsequently, $8-9 \mathrm{ml}$ of $0.9 \%$ saline was instilled five times via a tracheal cannula (bronchoalveolar lavage - BAL). The macrophages were collected from the BAL. The lungs were digested by protease solutions, then type II pneumocytes were obtained by the method of Richards et $a l^{5}$ and Hoet et $a l^{6}$. The cells were plated on 24-well plates (Gibco, $10^{6}$ cell $/ \mathrm{ml}$ ) and placed in a $\mathrm{CO}_{2}$ incubator for $20 \mathrm{~h}$ at $37^{\circ} \mathrm{C}$. Dulbecco's Modified Eagle's Medium (DMEM, Sigma) was changed after 20 h. DMEM contained the stone-wool (Republic of China, Gangzhou) and crocidolite fibres (Sheffield, UK) at concentrations of 1, $5,10 \mu \mathrm{g} / \mathrm{mland}$ were exposed for $20 \mathrm{~h}$. Control cells were exposed only to medium.

Biochemical analysis. After exposure to fibres, the supernatant was used for ELISA (see Immunology). The attached cells were treated with Triton X-100 (0.1\% v/v) for 
$10 \mathrm{~min}$ and the enzyme activities were determined. SOD, GSH-Px, GSH-Rd activity was measured with a Randox kit (Randox, Izinta, Budapest) ${ }^{7,8}$. GGT activity was determined by Szasz method ${ }^{9}$. AP activity was measured according to the DGKC (Deutsche Gesellschaft Klinische Chemie) method and protein content was determined by pyrogallic method (Ultrasensitive protein kit, AL instruments Ltd.). Each measurement was carried out by an automated method (AL+Clinical Chemical analyser) and all determinations were performed in duplicate. The results were expressed as milliunits of activity per milligram of protein.

Cytochemistry. Alkaline phosphatase (AP) activity. Control and treated cells were incubated in a mixture of AS-TR phosphate (Sigma) and Fast Red (Sigma) at $\mathrm{pH} 8.4$ in wells at room temperature (RT) for $30 \mathrm{~min}$. Positive cells were stained bright red. Only cells with four or more lamellar bodies were considered to be type II cells $^{10}$. Altogether 1000 cells were counted; positive cells were expressed in percentage of 1000 cells.

Lectin histochemistry. Pneumocytes and macrophages were fixed in neutral buffered formalin ( $\mathrm{pH} 7.4)$ for $10 \mathrm{~min}$ at RT. The cells were incubated with biotinylated lectins (20 $\mu \mathrm{g} / \mathrm{ml}$, Sigma) for $20 \mathrm{~min}$ at RT. Maclura pomifera agglutinin (MPA) is a characteristic of terminal $\alpha$-D-galactose/galactosamine moieties for the membranes of pneumocytes type II, Bandeiraea simplicifolia agglutinin (BSA) is a characteristic of terminal $N$-acetyl- $\alpha$-D-galactosamine sequences in the membrane of alveolar macrophages.

Immunology. Measurement of MCP-1 and MIP-1a levels from the supernatant of cultured AM and T2: the monoclonal antibody-based sandwich ELISA method was used for the measurement of MCP-1 and MIP- $1 \alpha$ levels in cell culture supernatants $\left(10^{6}\right.$ cells $\left./ \mathrm{ml}\right)$ of alveolar macrophages and pneumocytes type II. Optical densities were measured at $405 \mu \mathrm{m}$ wavelength using multiscan ELISA reader. Concentration of the samples was calculated using the calibration curve generated by software (Genesis).

Distribution of particle size. Particle size distribution and composition of stone-wool fibres are given in Table 1 and Table 2.

Statistical analysis. Results were expressed as means \pm SEM. All data were analysed by one-way ANOVA. The significant difference between the groups was tested using a two-way paired $t$ test. A value of $\mathrm{p}<0.05$ was considered to be significant.

\section{RESULTS AND DISCUSSION}

In alveolar macrophages stone-wool increased GSHPx, GSH-Rd activity ( $\mathrm{p}<0.01$, Fig. 1A, B), but the activity of $\mathrm{Cu}, \mathrm{Zn} / \mathrm{SOD}(\mathrm{p}<0.05$, Fig. $1 \mathrm{C}$ ) and AP activity decreased significantly ( $p<0.001$, Fig. 1D). Crocidolite significantly decreased the activity of each enzyme, except for $\mathrm{Cu}, \mathrm{Zn} / \mathrm{SOD}$ (Fig. 1C) and GGT (Fig. 1E).

In type II pneumocytes stone-wool decreased the activity of AP and GGT (*: p< 0.01, Fig. 2D, E), whereas UICC crocidolite significantly decreased the activity of all parameters (Fig. 2A, B, C, D, E).

The viability of both types of cells was $92-94 \%$ in controls (trypan blue exclusion test). The number of AP positive cells showed that the purity of culture averaged $81 \%$ in three experiments. The number of AP positive

Table 1. Distribution of particle size

\begin{tabular}{|c|c|c|c|}
\hline Length $[\mu \mathrm{m}]$ & \% fibres & diameter $[\mu \mathrm{m}]$ & \% fibres \\
\hline$<10$ & 24 & $\leq 1$ & 41 \\
\hline $10-20$ & 32 & $1-3$ & 30 \\
\hline $20-30$ & 13 & $\geq 3$ & 29 \\
\hline$>30$ & 31 & & \\
\hline
\end{tabular}

Table 2. Chemical composition of stone wool (CSR Guangzhou Office, China)

\begin{tabular}{|c|l|c|}
\hline Chemical mark & Name & Rate in \% \\
\hline $\mathrm{SiO}_{2}$ & Silicon oxide & $37.8 \%$ \\
\hline $\mathrm{Al}_{2} \mathrm{O}_{3}$ & Aluminium oxide & $13 \%$ \\
\hline $\mathrm{Fe}_{2} \mathrm{O}_{3}$ & Ferric oxide & $11.6 \%$ \\
\hline $\mathrm{FeO}$ & Ferrous oxide & $11.6 \%$ \\
\hline $\mathrm{CaO}$ & Calcium Oxide & $15.3 \%$ \\
\hline $\mathrm{TiO}_{2}$ & Titanium Oxide & $1.8 \%$ \\
\hline $\mathrm{MgO}^{\mathrm{Na}_{2} \mathrm{O}}$ & Magnesium Oxide & $11 \%$ \\
\hline & Sodium Oxide & $2.5 \%$ \\
\hline
\end{tabular}




\section{macrophages}

A

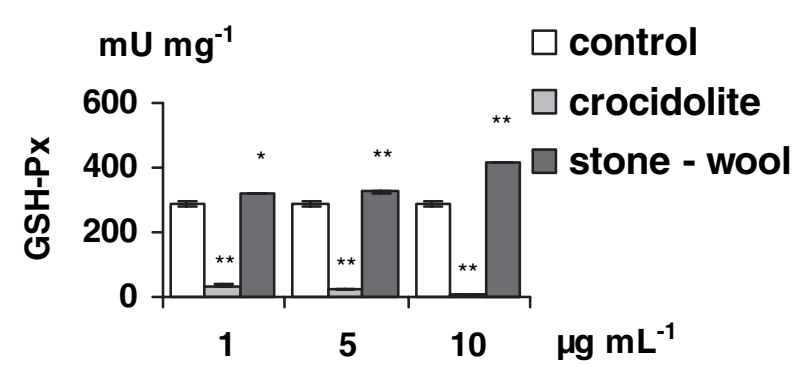

C

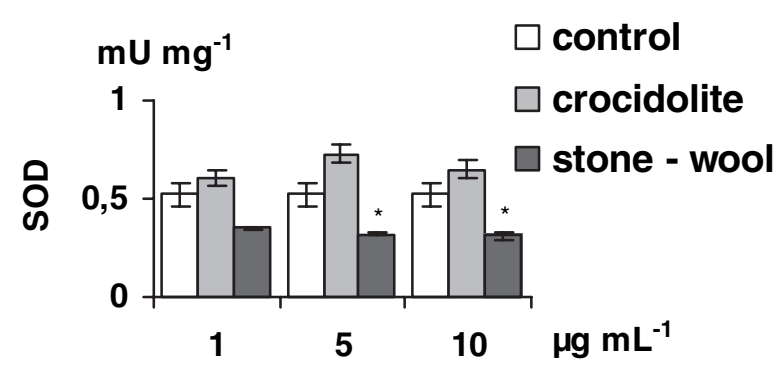

B

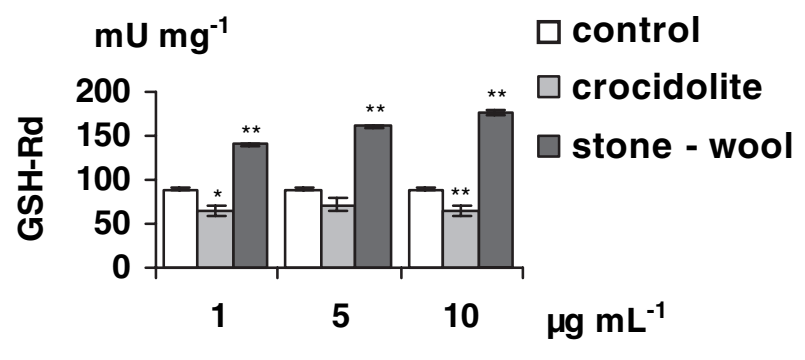

D

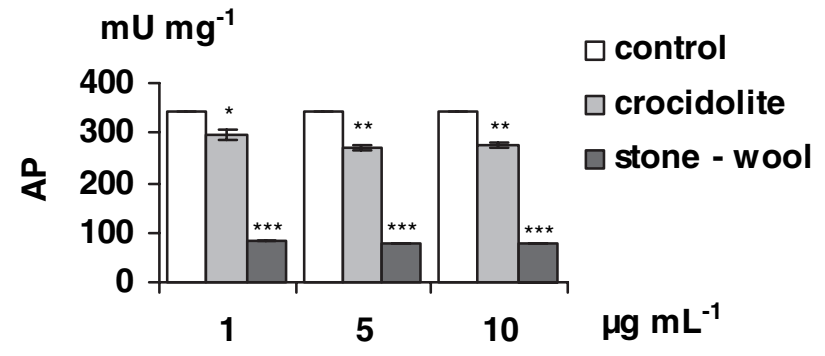

E

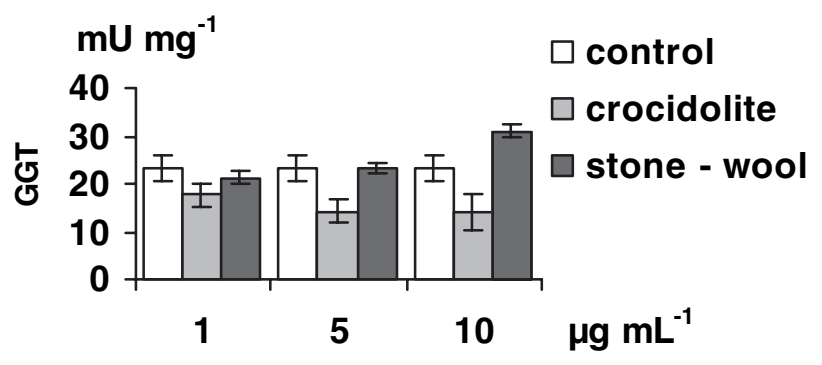

Fig. 1. Primary culture of alveolar macrophages after treatment with stone-wool and crocidolite. The data presented are means \pm SEM of three experiments (*: p < 0.05; ** : p < 0.01). A: activity of GSH-Px; B: activity of GSH-Rd; C: activity of $\mathrm{Cu}, \mathrm{Zn} / \mathrm{SOD}$; D: activity of AP; E: activity of GGT.

cells was $40 \%$ at $5 \mu \mathrm{g} / \mathrm{ml}\left(\mathrm{LC}_{50}\right)$ of stone wool, but $50 \%$ of pneumocytes was stained at $1 \mu \mathrm{g} / \mathrm{ml}\left(\mathrm{LC}_{50}\right)$ of crocidolite.

In lectin histochemistry, membranes of the control AM and type II showed regular, linear staining with BSA and MPA. Under the effect of crocidolite, at $1 \mu \mathrm{g} / \mathrm{ml}$, membranes of AM fragmented irregularly and frustrated phagocytosis could be found in AM. Stone-wool injured the membranes moderately at $5 \mu \mathrm{g} / \mathrm{ml}$ and gave rise to incomplete phagocytosis in a small fraction of cells.
Stone-wool decreased the activity of $\mathrm{Cu}, \mathrm{Zn} / \mathrm{SOD}$ in the alveolar macrophages and GGT activity in pneumocytes II. With the reduction of these enzymes, stone-wool decreased the adaptive mechanism of these cells ${ }^{11}$, however, to a lesser extent than crocidolite. On the basis of these results, stone-wool did not seem to be toxic to the enzymes of glutathione metabolism examined in cultured macrophages and pneumocytes type II. These effects may be related to very mild morphological changes

Immunological studies revealed that stone-wool and crocidolite significantly increased MCP-1 production in 

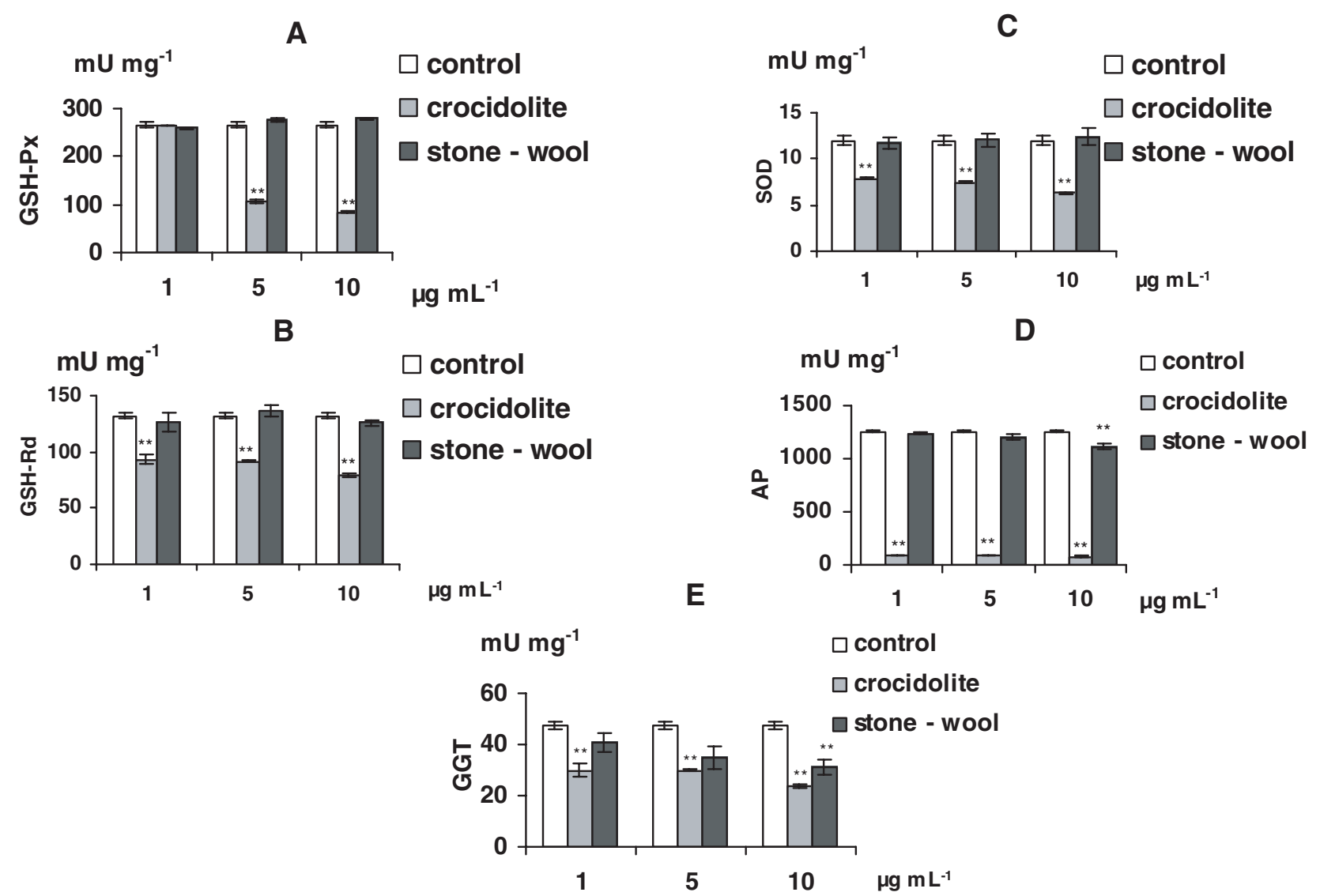 means \pm SEM of three experiments $(*: p<0.05 ; * *$ : $p<0.01)$. A: activity of GSH-Px; B: activity of GSH-Rd; C: activity of $\mathrm{Cu}, \mathrm{Zn} / \mathrm{SOD}$; D: activity of AP; E: activity of GGT.

Fig. 2. Primary culture of type II pneumocytes after treatment with stone-wool and crocidolite. The data presented are

A

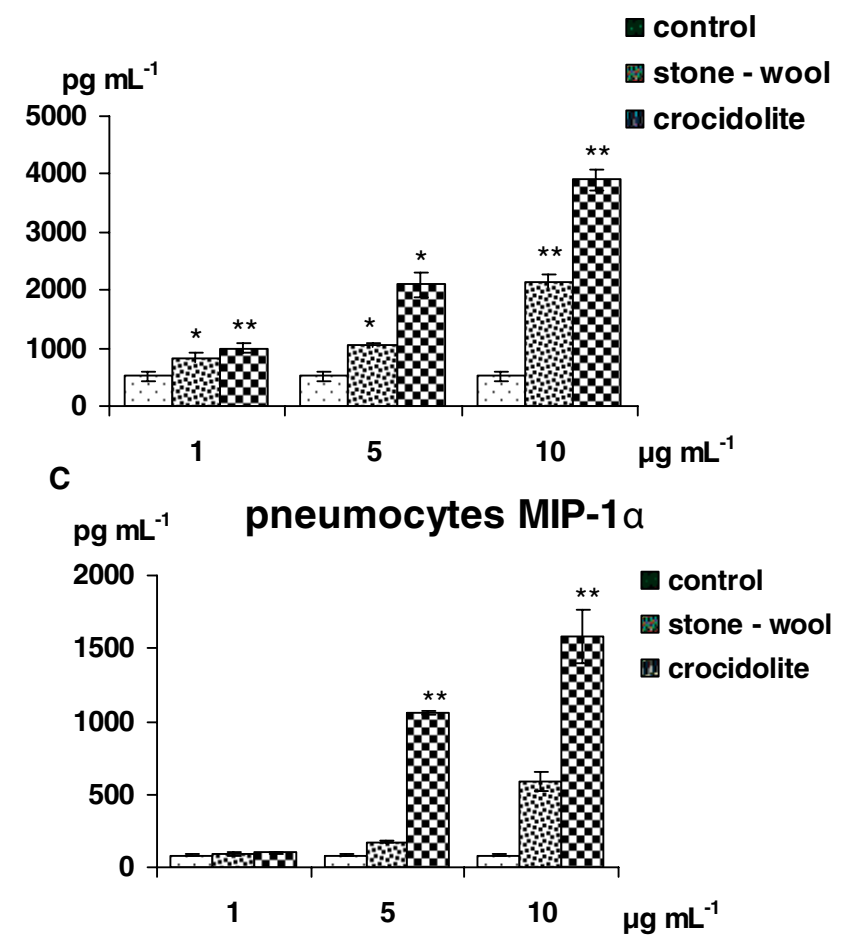

B (1)

D

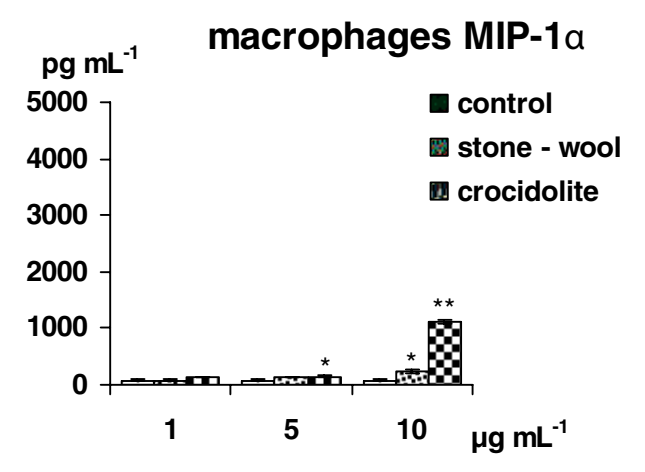

Fig. 3. Primary culture of pneumocytes type II and alveolar macrophages after treatment with stone-wool or crocidolite. The data presented are means \pm SEM of three experiments $\left({ }^{*}: \mathrm{p}<0.05 ;{ }^{* *}: \mathrm{p}<0.01\right)$. A: MCP-1 production in pneumocytes; B: MCP-1 production in macrophages; C: MIP-1 $\alpha$ production in pneumocytes; D: MIP-1 $\alpha$ production in macrophages. 
both AM and type II cells ( $p<0.01$, Fig. 3A, B) while the production of MIP-1 $\alpha$ was increased mainly in type II cells ( $p<0.01$, Fig. 3C, D). Crocidolite evoked higher production of both chemokines in both cell types than stone-wool.

Stone-wool induced the expression of MCP-1 and MIP$1 \alpha$ to a lesser extent than crocidolite what suggests moderate influence on the activity of alveolar macrophages and type II pneumocytes whithin alveolar space ${ }^{12,13}$. Although these chemokines may influence the outcome of pathological alterations on the basis of above results, it can not be definitely stated that stone-wool induced malignancies in the period examined.

Although this study provided a useful insight into the toxicity of the above fibres, we can not draw the conclusions how intact pulmonary tissue may respond to the exposure to these fibres.

\section{ACKNOWLEDGEMENT}

This research was supported by the Hungarian Scientific Research Fund (T-46773-OTKA) FIBRETOX (QLK4-199901629), Hungarian Research and Developmental Project (NKFP-1B047-07), Medical Research Council (ETT 154/ 2003-2006).

\section{REFERENCES}

1. IARC. Man-made vitreous fibres. IARC Monograph 81. Lyon: IARC, 2002. p. 338.

2. Kamp DW, Graceffa P, Pryor WA, Weitzman SA. (1992) The role of free radicals in asbestos-induced diseases. Free Radic Biol Med $11,568-76$

3. Quinlan TR, Marsh JP, Janssen YMW, Borm PA, Mossman BT. (1994) Oxygen radicals and asbestos mediated disease. Environ Health Perspect 102, 107-10.

4. Crapo JD, Harmsen AG, Sherman MP, Musson RA. (2000) Pulmonary immunobiology and inflammation in pulmonary diseases. Am J Respir Crit Care Med. 162, 1983-6.

5. Richards RJ, Davies N, Atkins J, Oreffo VIC. (1987) Isolation, biochemical characterisation and culture of lung epithelial cells of the rat. Lung 165,143-58.

6. Hoet PHM, Lewis CPL, Demedts M, Nemery B. (1994) Putrescine and paraquat uptake in human slices and isolated type II pneumocytes. Biochem Pharmacol 48, 517-24.

7. Fridovich I. (1986) Superoxide dismutases. Adv Enzymol 58, 61-97.

8. Meister A, Anderson ME. (1983). Glutathione. Annu Rev Biochem 52, 711-60.

9. Szasz G. (1969) A kinetic photometric method for serum gamma glutamyl transpeptidase. Clin Chem 15, 124-36.

10. Edelson JD, Shannon JM, Mason RJ. (1988) Alkaline phosphatase: a marker of alveolar type II cell differentiation. Am Rev Respir Dis 138, 1268-75.

11. Kugelman A, Choy HA, Liu R, Shi MM, Gozal E, and Forman HJ. (1994) Gamma glutamyl transpeptidase is increased by oxidative stress in rat alveolar T2 epithelial cells. Am J Respir Cell Mol Biol 11, 586-92.

12. Paine R, Rolfe MW, Standiford TJ, Burdick MD, Rollins BJ, Strieter RM. (1993) MCP-1 expression by rat type II alveolar epithelial cells in primary culture. J Immunol 150, 4561-70.

13. Vallyathan V, Shi X. (1997) The role of oxygen free radicals in occupational and environmental lung diseases. Environ Health Perspect 105, 165-77. 